\title{
Searching for humpback whales in a historical whaling hotspot of the Coral Sea, South Pacific
}

\author{
Claire Garrigue $^{1,2, *}$, Solène Derville ${ }^{1,2}$, Claire Bonneville ${ }^{2}$, C. Scott Baker ${ }^{3}$, \\ Ted Cheeseman ${ }^{4}$, Laurent Millet ${ }^{1}$, Dave Paton ${ }^{5}$, Debbie Steel ${ }^{3}$ \\ ${ }^{1}$ UMR ENTROPIE (IRD, Université de La Réunion, CNRS, Laboratoire d'excellence-CORAIL, \\ Université de la Nouvelle-Calédonie, IFREMER), 98848 Nouméa Cedex, Nouvelle-Calédonie, France \\ ${ }^{2}$ Opération Cétacés, Nouméa, 98802 Nouvelle-Calédonie, France \\ ${ }^{3}$ Marine Mammal Institute, Department of Fisheries and Wildlife, Oregon State University, Newport, OR 97365, USA \\ ${ }^{4}$ Southern Cross University, Lismore, NSW 2480, Australia \\ ${ }^{5}$ Blue Planet Marine, Kingston, ACT 2604, Australia
}

\begin{abstract}
Humpback whales Megaptera novaeangliae were severely depleted by commercial whaling. Understanding key factors in their recovery is a crucial step for their conservation worldwide. In Oceania, the Chesterfield-Bellona archipelago was a primary whaling site in the $19^{\text {th }} \mathrm{cen}$ tury, yet has been left almost unaffected by anthropogenic activities since. We present the results of the first multidisciplinary dedicated surveys in the archipelago assessing humpback whale populations 2 centuries post-whaling. We encountered 57 groups during 24 survey days (2016-2017), among which 35 whales were identified using photographs of natural markings (photo-ID), 38 using genotyping and 22 using both. Humpback whales were sparsely distributed ( 0.041 whales $\mathrm{km}^{-1}$ ): most sightings concentrated in shallow inner-reef waters and neighbouring offshore shallow banks. The recently created marine protected area covers most of the areas of high predicted habitat suitability and high residence time from satellite-tracked whales. Surprisingly for a breeding area, sex ratios skewed towards females (1:2.4), and $45 \%$ of females were with calf. Connectivity was established with the New Caledonia breeding area to the east $\left(\operatorname{mtDNA} F_{\mathrm{ST}}=0.001, \mathrm{p}>\right.$ 0.05, 12 photo-ID and 10 genotype matches) and with the Australian Great Barrier Reef breeding area to the west (mtDNA $\left.F_{\mathrm{ST}}=0.006, \mathrm{p}>0.05\right)$. Movement of satellite-tracked whales and photoID matches also suggest connections with the east Australian migratory corridor. This study confirms that humpback whales still inhabit the Chesterfield-Bellona archipelago 2 centuries post whaling, and that this pristine area potentially plays a role in facilitating migratory interchange among breeding grounds of the western South Pacific.
\end{abstract}

KEY WORDS: Chesterfield-Bellona archipelago - Connectivity · Coral Sea · Habitat use · Humpback whale $\cdot$ Satellite tracking $\cdot$ Sex ratio $\cdot$ Whaling

\section{INTRODUCTION}

Large whales were severely depleted by commercial whaling in the $19^{\text {th }}$ and $20^{\text {th }}$ centuries (Clapham 2016). Among them, humpback whale (Megaptera novaeangliae) populations of the Southern Hemisphere were decimated to only $1 \%$ of their pre-

${ }^{*}$ Corresponding author: claire.garrigue@ird.fr exploitation population sizes $(>210000$ whales taken between 1904 and 1972; Baker \& Clapham 2002). The whaling moratorium and local conservation efforts have allowed the partial recovery of most populations, with the exception of the breeding stocks of the Arabian Sea and Oceania that remain Endangered under the IUCN Red List (Childerhouse et al. restricted. Authors and original publication must be credited. 
2008). Indeed, the humpback whale breeding population of Oceania was estimated to be the least abundant in the Southern Hemisphere by Constantine et al. (2012). In western Oceania, 3 breeding sub-stocks have been recognized by the International Whaling Commission (IWC 2005): BSE1 (Great Barrier Reef, Australia), BSE2 (New Caledonia) and BSE3 (Tonga). Due to a historical lack of data, humpback whales migrating along the east Australian coast were considered to be a proxy for BSE1 and most of the literature referring to BSE1 were from data collected on this migratory corridor which could potentially be used by multiple stocks. Historically the Chesterfield-Bellona archipelago $\left(18.9^{\circ}\right.$ to $\left.21.9^{\circ} \mathrm{S}\right)$, located in the Coral Sea halfway between the east Australian coast and New Caledonia (see Fig. 1a), was considered as a potential breeding ground for humpback whales passing by the east Australian coast (Dawbin \& Falla 1949) during their northern migration from feeding Area V in the Antarctic.

Along with Tonga, this area was 1 of the 2 hotspots targeted by $19^{\text {th }}$ century commercial whaling of humpback whales in the South Pacific (Townsend 1935). Analysis of whalers' logbooks in the age of sail (Townsend 1935, Smith et al. 2012) gave an overview of the seasonal distribution of whales during this century and testified to the importance of the Chesterfield-Bellona archipelago (Smith et al. 2012). Wrecks (http://museemaritime.nc/fortunesdemer/naufrages) and remains of whaling stations (Guillou 1983) also attest to intense whaling activity during the $19^{\text {th }}$ century (Oremus \& Garrigue 2014), hence suggesting that humpback whales were abundant in these reefs at the time. Although recent scientific surveys and opportunistic sightings have reported the presence of humpback whales in the area (Gill et al. 1995, Oremus \& Garrigue 2014), the current status of the group of whales visiting the Chesterfield-Bellona archipelago is unknown. The origin and abundance of whales in this area is of particular interest as conservation measures will depend on whether the Chesterfield-Bellona archipelago humpback whales belong to the New Caledonia Endangered sub-stock (BSE2), to the healthy east Australian one (BSE1) or form a largely separate breeding population. Previous population dynamics and genetic analysis conducted in the breeding grounds of Oceania and east Australia highlighted potential exchanges and longitudinal migrations across the region (Valsecchi et al. 2010, Garrigue et al. 2011, Clapham \& Zerbini 2015, Steel et al. 2018). In this context, studying the connectivity between the Chesterfield-Bellona archipelago and the neighbouring coastal and oceanic breed- ing areas would fill a knowledge gap in our understanding of the population structure and trends within the Coral Sea (IWC 2011).

New Caledonia has recently created the Natural Park of the Coral Sea, covering 1.3 million $\mathrm{km}^{2}$, equivalent to $95 \%$ of New Caledonian waters (Decree of the Government of New Caledonia [GNC]: 20141063). This decision was made in concert with Australia as an international effort to protect both coastal and pelagic ecosystems within giant marine protected areas (MPAs; Lewis et al. 2017). In this context, MPAs were established within the Chesterfield-Bellona archipelago in 2018 (Decree GNC: 2018-1987). Ten integral reserves (IUCN category Ia; $6644 \mathrm{~km}^{2}$ ) were delimited, the largest one covering most of the northern waters in the Chesterfield plateau. These reserves are no-go areas, with highly restricted access only for the purposes of management or scientific activities. In addition, the natural reserve (IUCN category II; $20759 \mathrm{~km}^{2}$ ) encompasses all waters, surfacing reefs, cays and islands of the Chesterfield-Bellona archipelago above the $1000 \mathrm{~m}$ isobaths (excluding waters already included in the integral reserve). Access to this natural reserve by the general public and tourist operators is only granted through specific authorization (Decree GNC: 2018-1989). Fishing is totally prohibited in both types of MPAs. Marine mammals were explicitly targeted in objectives I and II of the management plan for these recently created MPAs (Decree: 2018-639), but their protective role for these species has not been evaluated.

The establishment of effective and representative MPAs is part of a global strategy to conserve biodiversity. Highly mobile and migratory species such as humpback whales typically represent a major challenge for spatial management because of their broadly distributed seasonal habitat (Wilhelm et al. 2014, White et al. 2017). Evaluating the current status of humpback whales in the Chesterfield-Bellona archipelago while there is still a paucity of data is therefore both a local conservation challenge and a key step towards better understanding of the habitat use and regional movement patterns of humpback whales in the Coral Sea. Using a multidisciplinary approach combining photo-identification (photo-ID), genetic analysis, habitat modelling, and satellite telemetry, this study aims to (1) assess whether humpback whales still occupy the Chesterfield-Bellona archipelago during the breeding season, (2) explore the habitats and activities of humpback whales in this offshore reef complex, (3) identify the breeding stock of any whales present in the Chesterfield-Bellona archipelago through the assessment of 
connectivity with neighbouring breeding sub-stocks BSE1 and BSE2 (IWC 2005) in New Caledonia and the Great Barrier Reef of Australia, respectively and (4) estimate the current level of protection for Chesterfield-Bellona archipelago humpback whales.

\section{MATERIALS AND METHODS}

\subsection{Study area}

The Chesterfield-Bellona archipelago lies in the Coral Sea between the east Australian coast and New Caledonia (Fig. 1). It constitutes one of the largest atolls in the world (Ceccarelli et al. 2013), covering about $16000 \mathrm{~km}^{2}$. The shallow plateaus (0-80 $\mathrm{m}$ depth) are surrounded by reefs, small islets and sand cays that form relatively sheltered lagoons, though most of the area remains largely open to the Coral Sea. Several shallow banks (0-30 m depth) are found between the 2 plateaus, as well as along the Lord Howe seamount chain extending south of Bellona plateau. For the purpose of this analysis, the study area is divided into 3 regions: the Bellona plateau, the Chesterfield plateau and the banks located between the 2 plateaus (Fig. 1).

\subsection{Data collection}

Surveys were conducted in the ChesterfieldBellona archipelago in 2016 (24 August-1 September) and 2017 (10-24 August) using 2 different oceanographic vessels. The timing of the surveys was
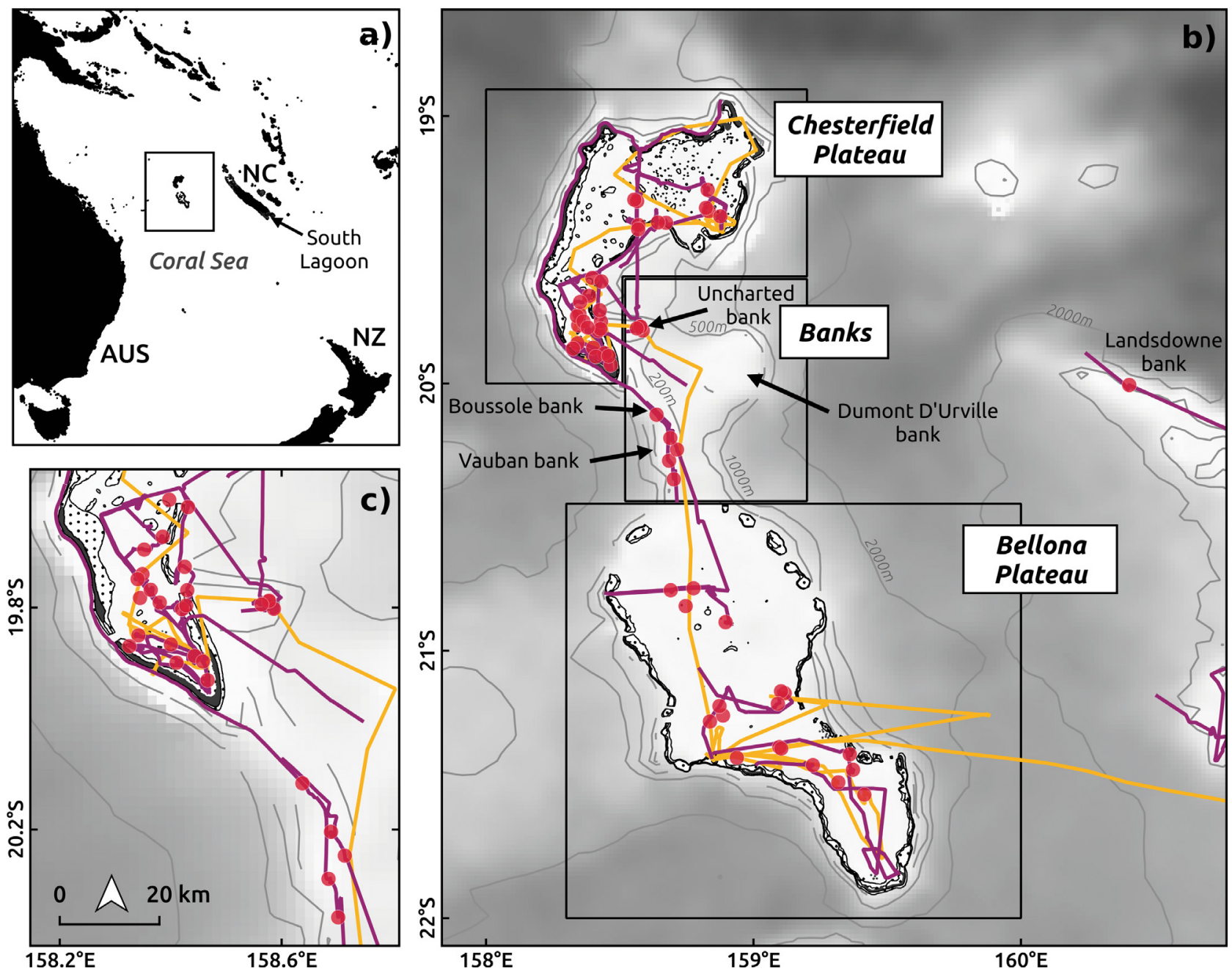

Fig. 1. Surveys of humpback whales Megaptera novaeangliae conducted in the Chesterfield-Bellona archipelago. (a) Chesterfield-Bellona in the Coral Sea (AUS: Australia; NZ: New Zealand; NC: New Caledonia). (b) Survey effort (orange: 2016, purple: 2017) and groups observed (red circles). (c) Zoom on the southern part of the Chesterfield plateau 
defined in relation to the peak of abundance of humpback whales Megaptera novaeangliae documented after mid-August in the South Lagoon of New Caledonia monitored for $>20$ yr (Derville et al. 2019a). Survey effort followed a non-systematic closing-mode protocol. Transect lines were determined on a daily basis and surveyed aboard the oceanographic vessels by 2 trained observers searching with the naked eye. When a group of humpback whales was detected and weather conditions allowed, a semi-inflatable boat was launched to conduct a focal follow. Once in close proximity to the group, the GPS position, time, group size, estimated age class of individuals (calf, juvenile, adult) and social group type (as defined by Clapham et al. 1992: singleton, pair, competitive group, mother with calf, mother with calf and escort, mother with calf in competitive group) were recorded.

During the focal follow, individual humpback whales were photographed using a digital camera Canon 40D and 50D alternatively equipped with a 70-300 mm lens or a 100-200 mm lens with $1.4 \times$ magnification. Both sides of the dorsal fin and the underside of the caudal fluke were photographed when possible. Tissue samples were collected from both adult and calf whales using either a crossbow with a specially adapted bolt (Lambertsen et al. 1994), or a modified 0.22 calibre capture veterinary rifle (Krützen 2002) or from collecting sloughed skin at the water surface after intense surface activities. In order to detect acoustic activities of singing males, a hydrophone (HighTech HTI 96MIN, frequency response $2 \mathrm{~Hz}$ to $30 \mathrm{kHz}$ ) connected to a Zoom H4 digital recorder (WAV format, 16 bit, sampling rate $44.1 \mathrm{kHz}$ ) was deployed opportunistically on 49 occasions.

Satellite tags were deployed on 6 adult whales using a modified pneumatic line-thrower (ARTS, Restech) set to pressure 10 bars (Heide-Jørgensen et al. 2001). SPLASH10 tags recording ARGOS locations (Wildlife Computers) were implanted next to the dorsal fin. Tags were duty-cycled to transmit every day, every other hour, with a maximum daily number of transmissions set to 400 .

\subsection{Encounter rates}

The distribution of humpback whales in the study area was estimated using an index accounting for the number of observations and the intensity of survey effort. The number of whales observed per kilometre of survey effort was calculated as the sum of group sizes observed per day of survey divided by the dis- tance surveyed per day $(\mathrm{km})$. The encounter rate was calculated by year over group sizes, then averaged across years.

\subsection{Photographic analysis}

Individual identification was performed through photo-ID of the underside of the fluke (Katona et al. 1979). The best photo-ID of each individual was used to create a catalogue of humpback whales collected in the Chesterfield-Bellona archipelago. Within the same season, comparison of dorsal fins was also performed in order to differentiate individuals whose flukes had not been photographed.

\subsection{Molecular analysis}

Genomic DNA was isolated from skin tissue by digestion with Proteinase $\mathrm{K}$, followed by phenol/ chloroform extraction and ethanol precipitation, according to Sambrook et al. (1989), modified for small samples (Baker et al. 1994). The sex of each whale sampled was identified by the amplification of a male-specific SRY marker, with a ZFX positive control, using primer pairs P15-EZ/P23-EZ (Aasen \& Medrano 1990) and Y53-3c/Y53-3d (Gilson \& Syvanen 1998).

Genotyping of humpback whales from Chesterfield-Bellona was conducted under the same conditions as for the genotyping of humpback whales from New Caledonia (1995-2017) and the Great Barrier Reef (2011-2017) following Steel et al. (2018). All coloaded PCR products were run on an ABI 3730xl sequencer at the Cetacean Conservation and Genomics Laboratory, OSU (Newport, OR, USA) and scored by the same researcher, thus providing calibration of microsatellite reading. Fifteen microsatellite loci were amplified using previously published primers: GATA28, GATA417 (Palsbøll et al. 1997b); 464/465 (Schlötterer et al. 1991); EV1, EV14, EV21, EV37, EV94, EV96 (Valsecchi \& Amos 1996); GT211, GT23, GT575 (Bérubé et al. 2000); and rw31, rw4-10, rw48 (Waldick et al. 1999). A subset of 6 known genotypes was re-amplified to look for potential genotyping errors. The software GENEMAPPER V3.7 (Applied Biosystems) was used to size alleles: peaks were visually assessed and bins manually checked. Only those samples that amplified for a minimum of 12 microsatellites were retained for further analyses.

Replicate samples within the Chesterfield-Bellona dataset were identified using the software CERVUS 
(Kalinowski et al. 2007) and required a minimum of 10 matching loci. The probability of identity (PID) was calculated using GenAlEX (Peakall \& Smouse 2006) and corresponds to the probability that 2 randomly selected samples will have matching genotypes.

A fragment of the mitochondrial DNA control region (mtDNA CR, approximately 800 bp) was amplified and sequenced using the primers lightstrand tPro-whale Dlp-1.5 (Baker et al. 1998) and heavy-strand Dlp-8G (Lento et al. 1997). Sequencing was performed on a 3130xl Genetic Analyzer (Applied Biosystems). Sequences were visualized and manually edited with Geneious R7. Clustal W alignment using sequences from the ChesterfieldBellona archipelago and sequences from Olavarría et al. (2007) was performed in order to highlight polymorphic sites and name haplotypes with nomenclature known in the South Pacific. Poor-quality sequences and those that represented possible new haplotypes were repeated or removed from the dataset following guidelines reported in Morin et al. (2010). The program Arlequin 3.5 (Excoffier \& Lischer 2010) was used to estimate genetic diversity on mtDNA CR haplotypes by calculating haplotypic diversity $(H)$.

\subsection{Habitat modelling}

Habitat suitability was predicted over the study area using a model developed by Derville et al. (2019b) from boat-based surveys conducted over 7 countries and territories in Oceania. A binomial generalized additive model was used to fit regional humpback whale relationships with depth, distance to reef or coasts, seabed slope, and the mean/variance of sea surface temperature, within eastern Oceania (French Polynesia), central Oceania (Samoa, American Samoa, Niue and Tonga) and western Oceania (Chesterfield-Bellona, New Caledonia and Vanuatu). The western Oceania dataset covered $710 \mathrm{~d}$ of survey effort from 2003 to 2017, of which 30 d were spent in the Chesterfield-Bellona archipelago in 2010, 2016 and 2017. This dataset included 1599 humpback whale group sightings, of which 57 were made in the Chesterfield-Bellona archipelago. Only this part of the model was effectively used in the present study to predict habitat suitability for humpback whales of all social group types over the Chesterfield-Bellona archipelago. Further details regarding this model may be found in Derville et al. (2019b). The areas of highest habitat suitability (val- ues > 0.95 quantile within the regions) were then compared with the extent of the integral and natural reserves of the Chesterfield-Bellona archipelago. The amount of coverage of suitable habitats provided by these 2 MPAs was calculated.

\subsection{Satellite tracking}

ARGOS locations were filtered to remove invalid locations of class $\mathrm{Z}$, locations on land and locations implying unrealistically rapid movements (speed > $18 \mathrm{~km} \mathrm{~h}^{-1}$; Zerbini et al. 2015). Whenever a track was interrupted for $>72 \mathrm{~h}$, the track was considered to be constituted of several segments, which were modelled separately. Track segments were interpolated at 1 position every $6 \mathrm{~h}$, hereinafter referred to as crawl-estimated locations, with a continuous-time correlated random walk model using the R package 'crawl' version 2.1.1 (Johnson et al. 2008). The error on ARGOS positions was incorporated as the ellipses semi-minor and semi-major axis error, with deployment GPS positions included and ellipses logarithmic error set to 0 . The beta parameter (representing velocity autocorrelation) was constrained between $[-3,4]$ bounds and was optimized using a normal distribution prior with mean -0.15 and SD 1.5. The sigma parameter was left unconstrained.

Finally, the first $24 \mathrm{~h}$ of tracking per individual were removed, assuming that subsequent locations would be independent from the position of tag deployment. The remaining crawl-estimated locations were used to calculate the average time spent by the tagged whales (1) within each of the 3 regions and (2) within the integral reserve and the natural reserve established in 2018 in the Chesterfield-Bellona archipelago. These percentages of time were estimated with respect to the total track sections occurring within the Chesterfield-Bellona archipelago delimited by the 3 study regions.

\subsection{Regional connectivity}

Population structure and regional differentiation were analysed at 2 scales, using both the comparisons of genotype catalogues and the estimation of differentiation indices. First, at the Oceania scale, the genetic dataset collected at Chesterfield-Bellona in 2016-2017 was compared with the available dataset of Oceania used by Steel et al. (2018). Then, at the scale of the Coral Sea it was compared with the entire datasets from New Caledonia (1995-2017) 
Table 1. Summary of samples available for genetic comparison using humpback whales Megaptera novaeangliae from Chesterfield-Bellona archipelago at the Oceania spatial scale (dataset from Steel et al. 2018) and at the Coral Sea scale, and haplotypic diversity $(H)$ calculated in the present study

\begin{tabular}{|lcccr|}
\hline Region & Years & Unique genotypes & No. of haplotypes & $H$ \\
\hline Chesterfield-Bellona archipelago & $2016-2017$ & 38 & 35 & $0.963 \pm 0.013$ \\
Oceania scale (from Steel et al. 2018) & & & 364 & \\
New Caledonia & $1995-2005$ & 377 & 323 & $0.973 \pm 0.002$ \\
Tonga & $1991-2005$ & 346 & 82 & $0.963 \pm 0.003$ \\
American Samoa/Samoa & $2001-2009$ & 88 & 92 & $0.930 \pm 0.015$ \\
Cook Islands & $1996-2005$ & 98 & 192 & $0.920 \pm 0.011$ \\
French Polynesia & $1997-2007$ & 207 & 1357 & $0.973 \pm 0.001$ \\
Coral Sea scale & & & 77 & $0.966 \pm 0.007$ \\
New Caledonia & $1995-2017$ & 1402 & 78 & \\
Australian Great Barrier Reef & $2011-2017$ & & & \\
\hline
\end{tabular}

and from the Australian Great Barrier Reef (20112017, Table 1). Comparisons between these areas $\left(F_{\mathrm{ST}}\right.$ on mtDNA $\left.C R\right)$ were calculated using Arlequin 3.5 (Excoffier \& Lischer 2010). The significance of regional differentiation was tested with 10000 random permutations.

Genotype comparisons to identify whales sampled across regions were also performed between the Chesterfield-Bellona and New Caledonia ( $\mathrm{N}=1402$ genotypes) and Great Barrier Reef ( $\mathrm{N}=78$ genotypes) datasets with the software CERVUS using the same protocol as described in Section 2.5.

Finally, regional connectivity was also investigated through photo-ID comparisons. Photographs of caudal flukes from Chesterfield-Bellona were compared to the New Caledonian catalogue $(\mathrm{N}=$ 1545) using Fluke Matcher software, a computerassisted matching program (Kniest et al. 2010), and visually confirmed. When no match was detected by this program, visual comparison was performed on a pairwise basis with the New Caledonian catalogue to confirm the identification of new individuals. In order to reveal potential connections with the east Australian breeding sub-stock E1 (Jackson et al. 2015), the photographs of caudal flukes were compared on a pairwise basis to recent Great Barrier Reef catalogue $(\mathrm{N}=79)$ issued from surveys conducted in 2016 and 2017 (Blue Planet Marine 2018), and an automated image recognition was performed to compare with 1981 individuals from the east Australian migratory corridor included in the Happywhale dataset (https://happywhale. com/home).

\section{RESULTS}

\subsection{Encounter rates}

In total, 13 humpback whale (Megaptera novaeangliae) groups were observed in 2016 and 44 in 2017 (Fig. 1), with a majority in Chesterfield plateau (53\%) and Bellona plateau (32\%, Table 2). Numerous groups were observed in the southern part of the Chesterfield plateau, and the central part of the Bellona plateau. On average, the highest encounter rate was found for the offshore banks (0.041 whales $\mathrm{km}^{-1}$ over 2 years) despite low effort in this region. The values were comparable between the Chesterfield and Bellona plateaus, with a slightly higher number of whales per kilometre surveyed in Chesterfield plateau (0.038 whales $\mathrm{km}^{-1}$ ) compared to Bellona plateau $\left(0.035\right.$ whales $\left.\mathrm{km}^{-1}\right)$. In general, over the archipelago, the encounter rate was higher in 2017 $\left(0.051\right.$ whales $\left.\mathrm{km}^{-1}\right)$ than in 2016 (0.025 whales $\mathrm{km}^{-1}$; Table 2).

Table 2. Humpback whale (Megaptera novaeangliae) survey effort and observation summary per year and per region. Nw: number of whales observed (summed over all groups observed)

\begin{tabular}{|lcccccc|}
\hline Region & Year & $\begin{array}{c}\text { Distance } \\
\text { surveyed }(\mathrm{km})\end{array}$ & $\begin{array}{c}\text { Hours } \\
\text { surveyed }\end{array}$ & $\begin{array}{c}\text { No. of groups } \\
\text { observed }\end{array}$ & Nw & $\begin{array}{c}\mathrm{Nw} \\
\mathrm{km}^{-1}\end{array}$ \\
\hline Chesterfield & 2016 & 378 & 34.2 & 4 & 7 & 0.019 \\
& 2017 & 858 & 81.8 & 26 & 48 & 0.056 \\
Bellona & 2016 & 611 & 35.9 & 8 & 18 & 0.030 \\
& 2017 & 550 & 46.9 & 10 & 22 & 0.040 \\
Banks & 2016 & 89 & 5.3 & 1 & 2 & 0.022 \\
& 2017 & 216 & 17.9 & 8 & 13 & 0.060 \\
Total per year & $\mathbf{2 0 1 6}$ & $\mathbf{1 0 7 9}$ & $\mathbf{7 5 . 4}$ & $\mathbf{1 3}$ & $\mathbf{2 7}$ & $\mathbf{0 . 0 2 5}$ \\
& $\mathbf{2 0 1 7}$ & $\mathbf{1 6 2 4}$ & $\mathbf{1 4 6 . 4}$ & $\mathbf{4 4}$ & $\mathbf{8 3}$ & $\mathbf{0 . 0 5 1}$ \\
Total & & $\mathbf{2 7 0 2}$ & $\mathbf{2 2 1 . 8}$ & $\mathbf{5 7}$ & $\mathbf{1 1 0}$ & $\mathbf{0 . 0 4 1}$ \\
\hline
\end{tabular}




\subsection{Genetic diversity}

All the samples collected in Chesterfield-Bellona were successfully genotyped at a minimum of 12 loci (average: 14.5). The PID calculated for a minimum of 10 loci was less than $1 \times 10^{-12}$, which is small enough to consider that 2 identical genotypes at a minimum of 10 loci would belong to the same individual and 2 different genotypes would belong to 2 different individuals (Steel et al. 2018). The 6 samples reamplified to check for genotyping errors showed no mismatches between amplifications, suggesting a very low error rate. We consider the true error rate to be no more than that reported for the entire Oceania dataset (per allele: $0.58 \%$; per locus: $1.11 \%$ ) as reported in Constantine et al. (2012). The genotype catalogue of humpback whales from the Chesterfield-Bellona archipelago consisted of 38 individuals from 40 samples, with 10 males and 28 females, of which 4 were calves (Table 1 ). The sex ratio excluding calves of 1:2.4 in favour of females significantly differed from a 1:1 ratio (2-tailed binomial test: $\mathrm{p}=0.024$ ).

A total of $35 \mathrm{mtDNA}$ CR were sequenced from the 38 individuals. Clustal W alignment of the $469 \mathrm{bp}$ consensus region resolved 19 haplotypes defined by 44 polymorphic sites in the Chesterfield-Bellona archipelago (Table S1 in the Supplement at www. int-res.com/articles/suppl/n042p067_supp.pdf). $H$ is 0.963 (SD 0.013) for the Chesterfield-Bellona archipelago, 0.973 (SD 0.001) for New Caledonia and 0.966 (SD 0.007) for the Australian Great Barrier Reef (Table 1). Of the 19 haplotypes defined in the Chesterfield-Bellona archipelago, 18 were also found in New Caledonia and 12 were also found in the Australian Great Barrier Reef. Only 1 haplotype (SP57) was not found in either of these 2 breeding grounds.

\subsection{Group composition}

Only 1 competitive group of 5 adults was encountered in 2016; the other groups were mothers with calf $(n=4)$, mothers with calf and escort $(n=1)$, pairs of 2 adults $(n=4)$ and 3 unidentified social group types. In 2017, one competitive group of 6 adults was also briefly observed; the other groups were mothers with calf $(n=17)$, mothers with calf and escort $(n=2)$, mothers with calf within competitive group $(\mathrm{n}=1)$, pairs of 2 adults $(\mathrm{n}=11)$ and singletons $(\mathrm{n}=12)$. In total, mothers with calf were present in $44 \%$ of all the groups encountered. Finally, humpback whale songs were heard in $61 \%$ of the hydrophone deployments
( $n=49$ ) conducted in 2016 over the whole Chesterfield-Bellona archipelago.

\subsection{Habitat suitability and use}

Maps of predicted habitat suitability suggested that humpback whales were more likely to occupy the shallow waters (around $50 \mathrm{~m}$ deep) located inside the plateaus (central Chesterfield and north Bellona) and over the unsheltered banks of La Boussole, Vauban, Dumont D'Urville and an uncharted bank (Fig. 2). External slopes and deep waters surrounding the plateaus were found to be relatively unsuitable.

These patterns of habitat preferences were also reflected in individual movements recorded through satellite tracking. Five of the 6 tagged whales were females; 3 of these were accompanied by a calf. The satellite tags transmitted for between 5 and $70 \mathrm{~d}$, during which the whales covered between 390 and $>5000 \mathrm{~km}$ (Table S2 in the Supplement). While in the Chesterfield-Bellona archipelago, tagged whales spent an average of $45.7 \%$ of their time (SD $44.2 \%$ ) in the Chesterfield plateau, $46.2 \%$ (SD $43.0 \%$ ) in the Bellona plateau and $8.2 \%$ (SD 9.2\%) in the offshore banks. They showed a preference for shallow waters inside the plateaus, in contrast with the surrounding deeper waters that were only occupied during transiting periods (Fig. 2a). Specifically, females with a calf tagged in Chesterfield plateau $(\mathrm{n}=2)$ and the offshore banks $(n=1)$ spent time in the southern sheltered waters of the Chesterfield (e.g. tag PTT 34227) and Bellona (PTT 34222) plateaus, and moved between them. This use of shallow waters outside lagoon areas is also illustrated by the stop-overs of 2 whales on the Kelso and Capel seamounts during their southward migration, including 1 with a calf (PTT 34226 and 34222, Fig. 2b).

The natural and integral reserves of the Chesterfield-Bellona archipelago covered part of the areas of effective and predicted use by humpback whales. Habitats with the highest predicted suitability were covered at $74 \%$ by the natural reserve and at $26 \%$ by the integral reserve (Fig. 3a). Similarly, tagged whales spent on average $51 \%$ (SD $38 \%$ ) of their time in the natural reserve, and $44 \%$ (SD $42 \%$ ) in the integral reserves (Fig. 3b).

\subsection{Regional connectivity}

Connectivity was assessed at different temporal scales: over the long term through genetic differenti- 

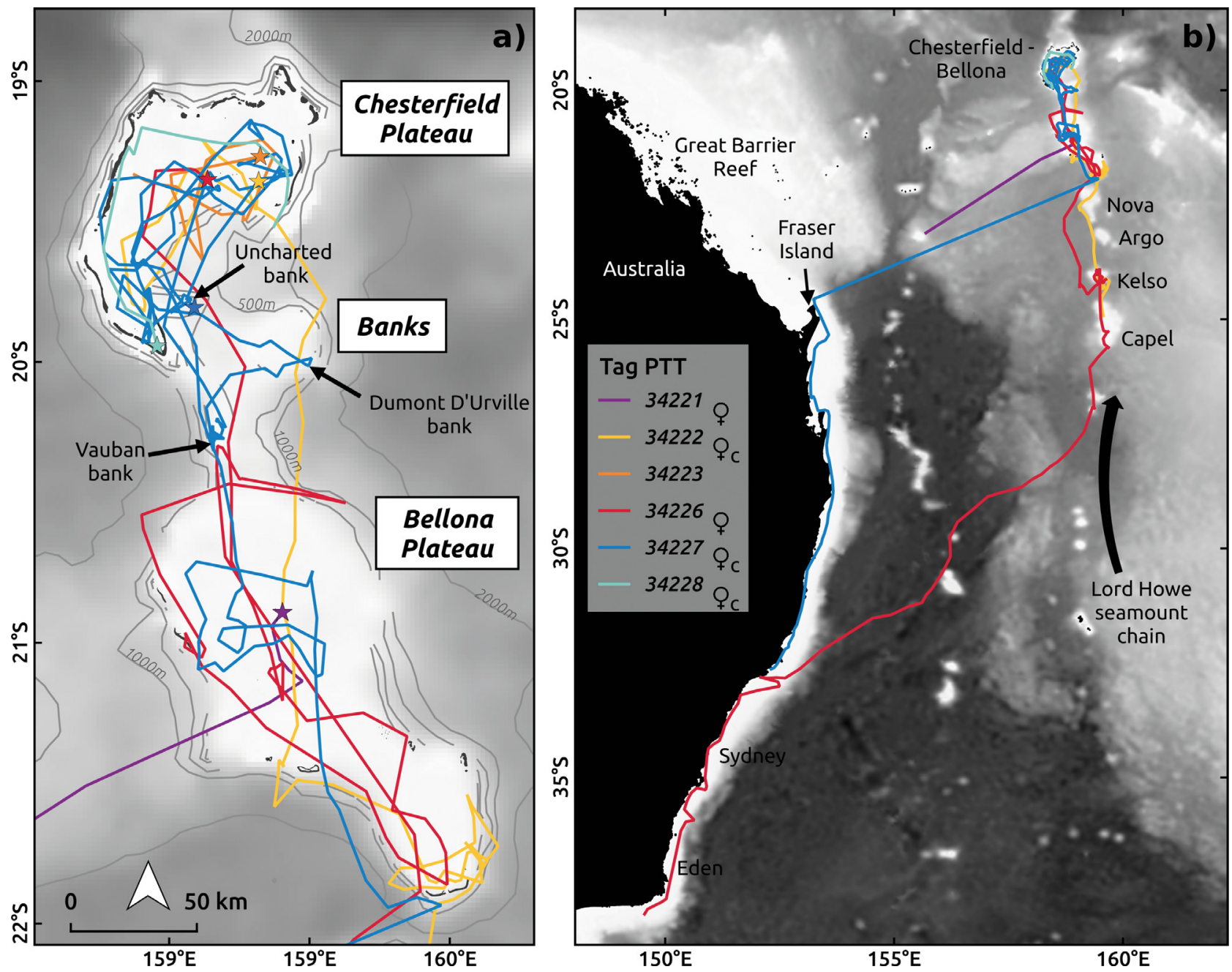

Fig. 2. Satellite tracking of 6 humpback whales Megaptera novaeangliae tagged in Chesterfield $(\mathrm{n}=4)$, Bellona $(\mathrm{n}=1)$, and the offshore banks ( $\mathrm{n}=1$ ) in 2017. (a) Zoom on the Chesterfield-Bellona archipelago, and (b) whole tracks from start to end of transmission. Tracks are modelled with a correlated random walk and interpolated with 1 location every 6 h. Deployment positions shown with stars. Sex and presence of a calf ('c') indicated in the tag colour key, except tag 34223 of unknown sex

ation, over a few years through photo-ID and genotype comparisons, and within a year through satellite telemetry.

Pairwise comparisons calculated on mtDNA CR data at the Oceania scale showed a significant differentiation between the Chesterfield-Bellona archipelago and all Oceania breeding grounds (Steel et al. 2018), including American Samoa $\left(F_{\mathrm{ST}}=0.023, \mathrm{p}<\right.$ $0.01)$, Cook Islands $\left(F_{\mathrm{ST}}=0.034, \mathrm{p}<0.001\right)$, French Polynesia $\left(F_{\mathrm{ST}}=0.038, \mathrm{p}<0.001\right)$ and Tonga $\left(F_{\mathrm{ST}}=\right.$ $0.011, \mathrm{p}<0.05)$, with the exception of New Caledonia $\left(F_{\mathrm{ST}}=0.001, \mathrm{p}>0.05\right.$, Table S3 in the Supplement). Pairwise $F_{\mathrm{ST}}$ comparisons calculated on mtDNA CR data at the scale of the Coral Sea provided no evidence of genetic differentiation between whales sampled in the Chesterfield-Bellona archipelago and the 2 breeding sub-stocks of the Australian Great Barrier Reef (BSE1; Table 3, $F_{\mathrm{ST}}=0.006, \mathrm{p}>0.05$ ) and of New Caledonia grounds (BSE2; Table $3, F_{\mathrm{ST}}=0.001$, $\mathrm{p}>0.05$ ). However, a weak but significant genetic differentiation is observed between the breeding substocks BSE1 and BSE2 (Table 3, $F_{\mathrm{ST}}=0.003, \mathrm{p}<0.05$ ).

Photo-ID and genotype comparisons led to the identification of 35 and 38 whales respectively. Of those whales identified by genotype, $58 \%$ are also known by photo-ID (Table S4 in the Supplement). No whale was re-sighted between 2016 and 2017. Thirty-four percent $(n=12)$ of the photo-identified whales, and $26 \%(n=10)$ of the whales identified with genotypes in the Chesterfield-Bellona archipelago were observed in New Caledonia in other years (Table S4), with 8 whales re-sighted by both methods 

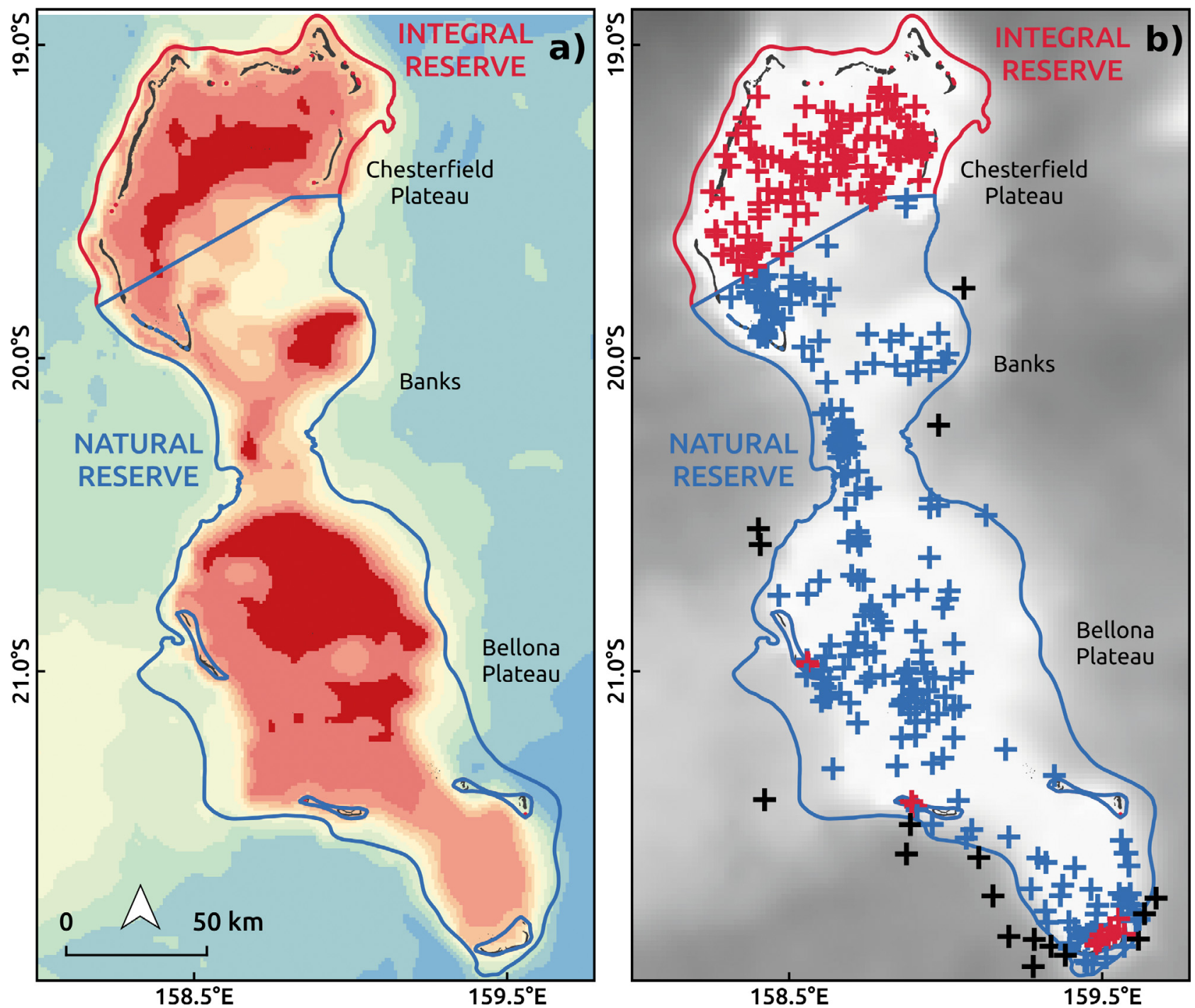

Fig. 3. Overlap between marine protected areas (red outline: integral reserve; and blue outline: natural reserve) and (a) predicted habitat suitability, and (b) satellite tracking of 6 humpback whales Megaptera novaeangliae tagged in the ChesterfieldBellona archipelago. In panel (a), predicted habitat suitability is represented on a colour scale, with blue representing the least suitable and red representing the most suitable habitat. The red areas of highest habitat suitability are covered at $74 \%$ by the natural reserve and $26 \%$ by the integral reserve. In panel (b), crawl-estimated locations are shown with blue crosses when they overlap with the natural reserve, and with red crosses when they overlap with the integral reserve. Tracking locations outside the reserves are shown with black crosses

(36\%). Four of the whales identified with only 1 method in the Chesterfield-Bellona archipelago had already been identified by both methods in New Caledonia (Table S5 in the Supplement). None of the re-sights between Chesterfield-Bellona archipelago and New Caledonia occurred within the same season. The longest lag between 2 re-sights was $19 \mathrm{yr}$ and the shortest was only 1 yr. Interestingly, most of these re-sighted whales had previously only been sighted in $1(n=12)$ or 2 different years $(n=1)$ in New Caledonia. Only 1 whale was observed in 4 different years. Moreover, $85 \%$ of the re-sighted whales were females $(n=11)$, of which $91 \%$ were observed at least once with a calf during the 2016-2017 expeditions or in previous years. Finally, no match was found between the individuals identified in the Chesterfield-Bellona archipelago and those recently photographed $(\mathrm{N}=79)$ and genotyped $(\mathrm{N}=78)$ in the Great Barrier Reef in 2016 and 2017 representing the breeding sub-stock BSE1. However, 4 whales (2 females and 2 males, Table S5) observed in the Chesterfield-Bellona archipelago have been previ- 
Table 3. Pairwise test of differentiation for humpback whale (Megaptera novaeangliae) mtDNA control region at haplotype level (conventional $F_{\mathrm{ST}}$ ) at the scale of the Coral Sea between Chesterfield-Bellona archipelago (2016-2017), New Caledonia (1995-2017) and the Australian Great Barrier Reef (2011-2017). Unadjusted for multiple comparison. $F_{\mathrm{ST}}$ indices and significance of pairwise differences (10 000 permutations) calculated in Arlequin (Excoffier \& Lischer 2010)

\begin{tabular}{|c|c|c|c|}
\hline Region (collection years) & $\begin{array}{l}\text { Chesterfield-Bellona } \\
\text { archipelago }\end{array}$ & $\begin{array}{c}\text { New } \\
\text { Caledonia BSE2 }\end{array}$ & $\begin{array}{l}\text { Great Barrier } \\
\text { Reef BSE1 }\end{array}$ \\
\hline $\begin{array}{l}\text { Chesterfield-Bellona archipelago (2016-2017) } \\
N=35\end{array}$ & - & & \\
\hline $\begin{array}{l}\text { New Caledonia (1995-2017) } \\
N=1357\end{array}$ & $\begin{array}{c}0.001 \\
p=0.344\end{array}$ & - & \\
\hline $\begin{array}{l}\text { Australian Great Barrier Reef (2011-2017) } \\
\mathrm{N}=77\end{array}$ & $\begin{array}{c}0.006 \\
\mathrm{p}=0.148\end{array}$ & $\begin{array}{c}0.003 \\
p=0.035\end{array}$ & - \\
\hline
\end{tabular}

ously observed on the east Australian corridor, and 3 of these individuals were also previously observed in New Caledonia.

Out of the 6 whales tagged in the Chesterfield-Bellona archipelago in 2017, 3 moved westward after leaving the Lord Howe seamount chain or the plateaus (Fig. 3b). Of those, the tag PTT 34221 stopped transmitting halfway between Bellona plateau and Australia, while the 2 other females (PTT 34227 with a calf, and PTT 34226) migrated south along the east Australian coast. Female 34227 reached the coast at Fraser Island $\left(25^{\circ} \mathrm{S}\right)$, while female 34226 followed the Lord Howe seamount chain and crossed the Coral Sea to reach the coast a little north of Sydney $\left(32^{\circ} \mathrm{S}\right)$. The latter was followed down to $38^{\circ} \mathrm{S}$, and the tag stopped emitting over the continental shelf south of Eden.

\section{DISCUSSION}

\subsection{Priority areas for conservation}

Identifying areas of importance for highly mobile migratory species is not an easy task (de Castro et al. 2014). The representativeness of the natural and integral reserves was inferred using the percentage of time that tagged humpback whales Megaptera novaeangliae spent in these MPAs and whether they encompassed the habitats with the highest predicted suitability. Since humpback whales use these areas for reproduction, the amount of time spent in an area is a good index to identify areas of interest for this species at this stage of their life cycle. First, we found that MPAs encompassed most of the areas where whales spent their time when in the ChesterfieldBellona archipelago. Yet, only a quarter of the habitats with the highest predicted suitability are covered by the integral MPA, which provides the highest level of protection, whereas three-quarters of these habitats were encompassed by the natural MPA where anthropogenic activities could still be undertaken under specific authorization (Decree GNC: 2018-1987 and 2018-1989). The divergence between MPAs offering the best protection to whales and their predicted suitable habitat is particularly noticeable on the shallow offshore banks, as well as on the great plateau of Bellona where no integral reserve has been planned but where whales spent a great part of their time ( $46 \%$ of their time). The telemetry results demonstrated that the percentage of time spent by tagged whales in both types of reserve is similar (Fig. 3b), implying that there is still potential for disturbance in a great part of the Chesterfield-Bellona archipelago. Uninhabited and located in a remote area of the natural park of the Coral Sea at $>25$ h sailing from New Caledonia mainland, the ChesterfieldBellona archipelago could therefore be currently considered pristine (Juhel et al. 2018). The potential for disturbance will therefore totally depend on the decision of the managers whether to allow visitors and activities into the natural reserve.

MPAs are a powerful tool for conservation and management of marine resources, but the levels of protection they provide can vary according to the goals of the management plan and its enforcement. Marine mammals have all the characteristics that make a species susceptible to becoming threatened: large size, long life, late breeding, few young, commercial value, international distribution across jurisdictions, and behaviour that makes them vulnerable to human activities (i.e. ship strike, pollution, entanglement). Important Marine Mammal Areas (IMMAs) have been specifically designated by the IUCN Marine Mammal Task Force to provide a novel scientific tool to lead place-based conservation of 
marine mammals (Corrigan et al. 2014, Notarbartolo di Sciara et al. 2016). The 'Chesterfield-Bellona Coral Reef Complex and Seamounts' area was proposed as a candidate IMMA in 2017, but did not pass selection at the time due to a lack of data. Based on new results acquired since then, we believe that this region will have the potential to be reconsidered as an IMMA in the future. Humpback whales will then fully play their role of an umbrella species of conservation, whose protection will be beneficial to other marine species that use the Chesterfield-Bellona archipelago, and specifically to lesser-known megafauna species (Borsa et al. 2010, Read et al. 2015, Clua \& Vignaud 2016, Juhel et al. 2018).

\subsection{Presence in post-whaling era}

Encounter rates recorded in 2016 and 2017 far exceeded previous estimates made in 2002 and 2010 on the Chesterfield plateau (0.020 and 0.003 whales $\mathrm{km}^{-1}$ surveyed, Oremus \& Garrigue 2014), and in 1992 when no whales were detected over $21 \mathrm{~h}$ of survey on the Bellona plateau (Gill et al. 1995). Although the 2002 and 2010 surveys also occurred in August, they differed from the present study in the extent of the area surveyed (mainly the southern part of the Chesterfield plateau versus the whole archipelago), time on-effort (relatively short: 41 and $26 \mathrm{~h}$ respectively in 2002 and 2010, versus 75 and 146 h in 2016 and 2017), and the logistic facilities deployed (sailing boats versus oceanographic vessels). Aside from a potential survey effort bias, the increase in the encounter rate observed in the 2016-2017 expeditions could be attributed to an increase in the number of whales visiting the Chesterfield-Bellona archipelago during the breeding season. Such an augmentation would be in line with the recovery of the Australian stocks (Noad et al. 2011), and to a lesser extent to the slower recovery of the breeding stocks of Oceania (Jackson et al. 2015).

Encounter rates measured in the Chesterfield-Bellona archipelago in 2016 and 2017 are comparable with those found in the New Caledonian South Lagoon $\left(0.045 \pm 0.018\right.$ whales $\mathrm{km}^{-1}$ from 2002 to 2010, Oremus \& Garrigue 2014), which has been subject to a long-term monitoring programme since 1995 (Garrigue et al. 2001). While these numbers suggest that humpback whales are present in the Chesterfield-Bellona archipelago, the density does not seem to be enough to have sustained the intense whaling activity in the 19th century. A few hypotheses can be considered: (1) whalers used to hunt despite these low densities, or (2) the archipelago sustained higher densities during the 19th century, or (3) current surveys have not covered the historical whaling sites. The first hypothesis is unlikely, as whaling expeditions were costly and had to be compensated by high catch rates. Concerning the second hypothesis, Smith et al. (2012, p. 11) recognized that 'some of the whale populations exploited in the 19th century are still far below their pre-whaling abundance; in some areas of formerly high-density occurrence, the animals are now absent or rare'. This consideration leads us to think that this population might have been extirpated by whalers or that the few remaining whales have deserted this area. Finally, the few data available from the whaling era do not provide any accurate location of the catches (Lund et al. 2018) and prevent us from validating the third hypothesis. Bourne et al. (2005, p. 255) noted that humpback whales 'apparently occurred all around the islands although they were commonest off the south end of the Bellona reefs'. Indeed, several whales tagged in 2017 (our Fig. 2b) and in previous studies (Garrigue et al. 2015) have spent time on the Lord Howe seamount chain located south of the Bellona plateau. Could these seamounts actually be the whaling sites that whalers' logbooks were referring to? Considering that American whalers were using sailing boats, they were more likely to work in the so-called 'South of Bellona' waters, referring to the Lord Howe seamount chain, than inside the southern part of the Bellona plateau, a shallow and reef-enclosed area where navigation by sail would be perilous. As humpback whales appear to have dynamic and changing distribution patterns through time and in response to environmental and social changes (Herman 1979, Clapham \& Zerbini 2015, Miller et al. 2015), a more exhaustive assessment of past and present numbers over the whole archipelago would be necessary to further test these hypotheses.

\subsection{Habitat use}

In humpback whale breeding grounds, the sex ratio is usually male-biased (Craig \& Herman 1997, Palsbøll et al. 1997a, Pomilla \& Rosenbaum 2006, Herman et al. 2011). In the Chesterfield-Bellona archipelago, the sex ratio measured was strongly in favour of females, due to a high proportion of females with a calf.

Female migratory timing is greatly influenced by their reproductive status, which results in a varying sex ratio of the breeding population along the season 
(Dawbin 1997, Craig et al. 2003). As females in late pregnancy are the last to arrive on the breeding grounds, and the last to depart for the feeding grounds (Dawbin 1997), a majority of maternal females should be observed at the end of the breeding season. The dominance of maternal females observed in the Chesterfield-Bellona archipelago in August was therefore unexpected, but could not be explained by a shift of the season's peak. The timing of the expeditions was planned to be in synchrony with the peak of the reproductive season in the New Caledonian South Lagoon, at a time where high agonistic activities should be observed and males should be in greater proportion than females (Garrigue et al. 2001). Moreover, if anything, the peak of the season in the Chesterfield-Bellona archipelago should be occurring later than that of the New Caledonian South Lagoon based on its lower latitude $\left(19-22^{\circ} \mathrm{S}\right.$ vs. $>22^{\circ} \mathrm{S}$ respectively), a factor that appears to drive late season peaks in American Samoa $\left(14^{\circ} \mathrm{S}\right.$; Munger et al. 2012) and French Polynesia (Society Islands; $17^{\circ} \mathrm{S}$, Poole 2002).

Female-biased sex ratios have been reported in the population of the Arabian Sea (Minton et al. 2011) and the west African and east Australian coastal migratory corridors (Barendse et al. 2010, Franklin et al. 2018), but never in a breeding ground before now. Two mechanisms could explain the high proportion of females with a calf encountered in the Chesterfield-Bellona archipelago. The first mechanism relates to energy conservation, as maternal females will search for areas with fewer males to minimize harassment from males seeking mating opportunities with post-partum females (Chittleborough 1958). Energy saving has been demonstrated in the Hawaiian breeding ground, where females with calf are thought to limit energy expenditure to focus on lactation and nursing (Craig et al. 2014). Indeed, the avoidance of male interaction could favour the calf's survival. This behavioural avoidance results in a social segregation of maternal females that has also been demonstrated in the New Caledonian South Lagoon (Derville et al. 2018). Social aggregation is another non-exclusive mechanism potentially explaining a female-biased sex ratio. Males and females might be recolonizing habitats differently and/or at different rates. Hence, the prevalence of mothers with a calf in the Chesterfield-Bellona plateaus could be explained by differential space use patterns between females and males, the latter being less inclined to remain within an area of low density and few breeding opportunities (Clapham \& Zerbini 2015). On the one hand, mothers with a calf are more likely to stay in the sheltered and warm waters of the plateaus known to be suitable nursing habitats (Derville et al. 2018). On the other hand, although songs were heard on the plateaus, only very few males were encountered. Nearby seamounts of the Lord Howe seamount chain (Kelso, Capel, Fig. 2b) might be more likely to concentrate mating opportunities, in a way similar to what is observed south of the New Caledonia mainland. There, whales navigate between the coastal sheltered waters of the New Caledonian South Lagoon and the unsheltered seamounts of the Norfolk ridge where males compete in greater numbers (Garrigue et al. 2017). By analogy, we hypothesize that males could preferentially aggregate in the Lord Howe seamount chain to find mating opportunities, whereas maternal females could preferentially use the inner waters of Chesterfield and Bellona plateaus. Surveying the seamounts of the Lord Howe seamount chain could provide a better understanding of this sex-biased spatial distribution pattern.

\subsection{Origin of the population and regional connectivity}

Although we acknowledge that the number of genetic samples collected in the Chesterfield-Bellona archipelago is relatively small, our results suggest that the humpback whales currently visiting this area are not significantly different from the breeding substocks BSE1 (Great Barrier Reef) and BSE2 (New Caledonia), as indicated by indices of differentiation based on mtDNA data. This contrasts with the genetic differentiation highlighted between the Chesterfield-Bellona archipelago and other breeding grounds in Oceania. It is possible that the original population of the Chesterfield-Bellona archipelago was extirpated by whalers, and that this suitable breeding habitat was progressively recolonized by animals originating from the 2 breeding sub-stocks of the southwest Pacific. Moreover, differentiation measured between breeding sub-stocks BSE1 and BSE2 is very weak and might suggest exchanges between them. The origin of the population from the Chesterfield-Bellona archipelago is challenging to identify, given the potential connectivity between the 2 sub-stocks. While they might have in the past, whales of the Chesterfield-Bellona archipelago do not currently form an independent population.

Photo-ID and genotype comparisons suggest a strong connectivity to the New Caledonian breeding sub-stock (BSE2), with a re-sighting rate between the 
Chesterfield-Bellona archipelago and the South Lagoon of the same order of magnitude as the resight rate within the South Lagoon (Garrigue et al. 2001). While no photographic or genetic recaptures have been observed between the Chesterfield-Bellona archipelago and New Caledonia within the same season to date, previous studies have shown that 7 whales tagged in the southern part of New Caledonia travelled in a westerly direction toward the central part of the Coral Sea (Garrigue et al. 2010, 2015). The tracks of these whales occurred during the second part of the breeding season, from the end of July to mid-October, suggesting a within-year connection with the Chesterfield-Bellona archipelago.

No match has been found between the Chesterfield-Bellona archipelago and the whales photoidentified or genotyped in the Great Barrier Reef (BSE1). This lack of photo-ID or genotype match could result from the small sample sizes of the catalogues from both areas. Four whales were photoidentified both in the Chesterfield-Bellona archipelago and over the east Australian migratory corridor, and a connection has been revealed by 3 whales tagged in the Chesterfield-Bellona archipelago which travelled to Australia and followed this migratory corridor. This result corroborates the speculations that the east Australian migratory corridor is used by whales from different breeding locations.

\section{CONCLUSIONS}

Humpback whales Megaptera novaeangliae still inhabit the Chesterfield-Bellona archipelago 2 centuries post-whaling but the density that is currently observed appears to be less than that present during the whaling era. Nevertheless, the Chesterfield-Bellona archipelago provides suitable habitat for reproduction, although its population displays atypical characteristics, namely a preponderance of mothers with a calf, leading to a female-biased sex ratio. We suggest that the whales currently observed in the Chesterfield-Bellona archipelago do not form a separate breeding population, although there is currently not enough evidence to decide which population the whales encountered in the Chesterfield-Bellona archipelago belong to. Genetic, photographic and telemetry analysis suggest a connection to both the New Caledonian breeding sub-stock and the east Australian one, at least to the east Australian migratory corridor. Further sampling in the ChesterfieldBellona archipelago and the Great Barrier Reef will resolve the relative strength of links to New Caledo- nia and east Australia and will help identify the population's origin.

The recent prohibition of all human activities within integral MPAs will preserve part of the humpback whales' suitable habitats and areas of use in the plateaus. However, we would also strongly recommend that higher levels of protections are provided for the banks located in the Chesterfield-Bellona archipelago, as well as for the shallow seamounts of the Lord Howe seamount chain. As a migratory species, humpback whales require seasonal protection rather than permanent MPAs. Therefore, the adoption of temporary protected areas to reflect the behaviour and dynamic distribution may present an alternative that is worth considering as a planning strategy for future MPAs (Asaro 2012). Finally, consistent monitoring will be necessary to follow the evolution of the population and adapt management measures for this pristine breeding ground and historical whaling site.

Acknowledgements. We thank all the people who contributed to this study, specifically the members of Opération Cétacés, Rémi Dodemont and Véronique Pérard. We thank Mike Williamson, the 'Amborella' crew and the 'Alis' crew for help in the field, and our interns for genetic analysis and Alex Zerbini and Leigh Torres for spatial analysis. Genetic analyses were performed at the Plateforme du Vivant, IRD (Noumea, New Caledonia), at the Cetacean Conservation and Genomics Laboratory, OSU (Newport, OR, USA) and at Genoscreen (France). This study was carried out following the marine mammal treatment guidelines of the Society for Marine Mammalogy. Fieldwork was undertaken under permits issued by the New Caledonian Government. Financial support was provided by the New Caledonian Government granting access to the 'Amborella' ship, the World Wildlife Fund for Nature France funding the satellite tags, the Ministère de la Transition Ecologique et Solidaire, Opération Cétacés and the International Whaling Commission through the SORP Project 'Movements and mixing of humpback whales around Antarctica'. Finally, we thank the 3 anonymous reviewers for their suggestions to improve the quality of the manuscript.

\section{LITERATURE CITED}

Aasen E, Medrano JF (1990) Amplification of the ZFY and ZFX genes for sex identification in humans, cattle, sheep and goats. Nat Biotechnol 8:1279-1281

Asaro MJ (2012) Geospatial analysis of management areas implemented for protection of the North Atlantic right whale along the northern Atlantic coast of the United States. Mar Policy 36:915-921

Baker CS, Clapham PJ (2002) Marine mammal exploitation: whales and whaling. In: Douglas I (ed) Causes and consequences of global environmental change, Book 3. John Wiley \& Sons, Chichester, p 446-450

Baker CS, Slade RW, Bannister JL, Abernethy RB and others (1994) Hierarchical structure of mitochondrial DNA gene 
flow among humpback whales Megaptera novaeangliae, world-wide. Mol Ecol 3:313-327

Baker CS, Flórez-González L, Abernethy B, Rosembaum HC, Slade RW, Capella J, Bannister JL (1998) Mitochondrial DNA variation and maternal gene flow among humpback whales of the southern hemisphere. Mar Mamm Sci 14:721-737

Barendse J, Best PB, Thornton M, Pomilla C, Carvalho I, Rosenbaum HC (2010) Migration redefined? Seasonality, movements and group composition of humpback whales Megaptera novaeangliae off the west coast of South Africa. Afr J Mar Sci 32:1-22

Kérubé M, Jørgensen H, McEwing R, Palsbøll PJ (2000) Polymorphic di-nucleotide microsatellite loci isolated from the humpback whale, Megaptera novaeangliae. Mol Ecol 9:2181-2183

Blue Planet Marine (2018) IWC SORP interim report April 2018: Who are the real east Australian (E1) breeding group of humpback whales? Genetic characterisation of E1 and the influence of E1 across Oceania. In: BPM-18IWC SORP-2017 GBR Survey Milestone 2 Report April 2018-v11

Korsa P, Pandolfi M, Andréfouët S, Bretagnolle V (2010) Breeding avifauna of the Chesterfield Islands, Coral Sea: current population sizes, trends, and threats. Pac Sci 64: 297-314

* Bourne WRP, David ACF, McAllan IAW (2005) The birds of the Southern Coral Sea including observations by HMS Herald in 1858-60. Atoll Res Bull 541:237-263

Ceccarelli DM, McKinnon AD, Andréfouët S, Allain V and others (2013) Chapter Four. The Coral Sea: physical environment, ecosystem status and biodiversity assets. Adv Mar Biol 66:213-290

Childerhouse S, Jackson J, Baker CS, Gales N, Clapham PJ, Brownell RL Jr (2008) Megaptera novaeangliae (Oceania subpopulation). IUCN Red List of Threatened Species 2008:e.T132832A3463914

Chittleborough RG (1958) The breeding cycle of the female humpback whale, Megaptera nodosa (Bonnaterre). Mar Freshw Res 9:1-18

* Clapham PJ (2016) Managing Leviathan: conservation challenges for the great whales in a post-whaling world. Oceanography (Wash DC) 29:214-225

Clapham PJ, Zerbini AN (2015) Are social aggregation and temporary immigration driving high rates of increase in some Southern Hemisphere humpback whale populations? Mar Biol 162:625-634

Clapham PJ, Palsbøll PJ, Mattila DK, Vasquez O (1992) Composition and dynamics of humpback whales competitive groups in the West Indies. Behaviour 122: 182-194

* Clua E, Vignaud T (2016) Possible collapse of reef shark populations in remote coral reef ecosystems in the Coral Sea (Western Pacific). Cybium 40:51-59

* Constantine R, Jackson JA, Steel D, Baker CS and others (2012) Abundance of humpback whales in Oceania using photo-identification and microsatellite genotyping. Mar Ecol Prog Ser 453:249-261

Corrigan CM, Ardron JA, Comeros-Raynal MT, Hoyt E, Notarbartolo Di Sciara G, Carpenter KE (2014) Developing important marine mammal area criteria: learning from ecologically or biologically significant areas and key biodiversity areas. Aquat Conserv 24:166-183

Craig AS, Herman LM (1997) Sex differences in site fidelity and migration of humpback whales (Megaptera no- vaeangliae) to the Hawaiian Islands. Can J Zool 75: 1923-1933

* Craig AS, Herman LM, Gabriele CM, Pack AA (2003) Migratory timing of humpback whales (Megaptera novaeangliae) in the central North Pacific varies with age, sex and reproductive status. Behaviour 140: 981-1001

Craig AS, Herman LM, Pack AA, Waterman James O (2014) Habitat segregation by female humpback whales in Hawaiian waters: avoidance of males? Behaviour 151: $613-631$

Dawbin WH (1997) Temporal segregation of humpback whales during migration in Southern Hemisphere waters. Mem Queensl Mus 42:105-138

Dawbin WH, Falla RA (1949) A contribution to the study of the humpback whale based on observations at New Zealand Shore stations. In: Proc 7th Pac Sci Congr, Pac Sci Assoc

de Castro FR, Mamede N, Danilewicz D, Geyer Y, Pizzorno JLA, Zerbini AN, Andriolo A (2014) Are marine protected areas and priority areas for conservation representative of humpback whale breeding habitats in the western South Atlantic? Biol Conserv 179:106-114

* Derville S, Torres LG, Garrigue C (2018) Social segregation of humpback whales in contrasted coastal and oceanic breeding habitats. J Mammal 99:41-54

* Derville S, Torres LG, Dodemont R, Pérard V, Garrigue C (2019a) From land and sea, long-term data reveal persistent humpback whale breeding habitat in New Caledonia. Aquat Conserv 29:1697-1711

* Derville S, Torres LG, Albertson R, Andrews O and others (2019b) Whales in warming water: assessing breeding habitat diversity and adaptability in Oceania's changing climate. Glob Change Biol 25:1466-1481

Excoffier L, Lischer HEL (2010) Arlequin suite ver 3.5: a new series of programs to perform population genetics analysis under Linux and Windows. Mol Ecol Resour 10: 564-567

Franklin T, Franklin W, Brooks L, Harrison PL (2018) Sitespecific female-biased sex ratio of humpback whales (Megaptera novaeangliae) during a stopover early in the southern migration. Can J Zool 96:533-544

Garrigue C, Greaves J, Chambellant M (2001) Characteristics of the New Caledonian humpback whale population. Mem Queensl Mus 47:539-546

*Garrigue C, Zerbini AN, Geyer Y, Heide-Jørgensen MP, Hanaoka W, Clapham P (2010) Movements of satellitemonitored humpback whales from New Caledonia. J Mammal 91:109-115

Garrigue C, Franklin T, Russell K, Burns D and others (2011) First assessment of interchange of humpback whales between Oceania and the east coast of Australia. J Cetacean Res Manag Spec Issue 3:269-274

Garrigue C, Clapham PJ, Geyer Y, Kennedy AS, Zerbini AN (2015) Satellite tracking reveals novel migratory patterns and the importance of seamounts for endangered South Pacific humpback whales. R Soc Open Sci 2:150489

Garrigue C, Bonneville C, Derville D, Dodemont R, Oremus M, Pérard V (2017) Humpback whale offshore breeding grounds in the South Pacific: unravelling the network. 22nd Biennial Conference on the Biology of Marine Mammals, Halifax, NS, Canada, Oct 2017

Gill PC, Eyre EJ, Garrigue C, Dawbin WH (1995) Observations of humpback whales (Megaptera novaeangliae) on 
a cruise to New Caledonia and the Chesterfield reefs. Mem Queensl Mus 38:505-511

Gilson A, Syvanen M (1998) Deer gender determination by polymerase chain reaction: validation study and application to tissues, bloodstains and hair forensic samples from California. Calif Fish Game 84:159-169

Guillou J (1983) Trois naufrages aux Iles Chesterfield au siècle dernier. Bull Soc Hist Nouméa 55

*Heide-Jørgensen MP, Kleivane L, Øien N, Laidre KL, Jensen MV (2001) A new technique for deploying satellite transmitters on baleen whales: tracking a blue whale (Balaenoptera musculus) in the North Atlantic. Mar Mamm Sci 17:949-954

Herman LM (1979) Humpback whales in Hawaiian waters: a study in historical ecology. Pac Sci 33:1-15

Herman LM, Pack AA, Rose K, Craig A, Herman EYK, Hakala S, Milette A (2011) Resightings of humpback whales in Hawaiian waters over spans of 10-32 years: site fidelity, sex ratios, calving rates, female demographics, and the dynamics of social and behavioral roles of individuals. Mar Mamm Sci 27:736-768

International Whaling Commission (IWC) (2005) Report of the Sub-Committee on Other Southern Hemisphere Whale Stocks. J Cetacean Res Manag 7(Suppl):235-244

IWC (2011) Report of the Workshop on the Comprehensive Assessment of Southern Hemisphere Humpback Whales. Annex H: Recommendations for each breeding stock. J Cetacean Res Manag Spec Issue 3:1-50

Jackson J, Ross-Gillespie A, Butterworth D, Findlay K and others (2015) Southern hemisphere humpback whale comprehensive assessment a synthesis and summary: 2005-2015. Report SC/66a/SH3 to the Scientific Committee of the International Whaling Commission

Johnson D, London J, Lea MA, Durban J (2008) Continuoustime correlated random walk model for animal telemetry data. Ecology 89:1208-1215

Juhel JB, Vigliola L, Mouillot D, Kulbicki M, Letessier TB, Meeuwig JJ, Wantiez L (2018) Reef accessibility impairs the protection of sharks. J Appl Ecol 55:673-683

Kalinowski ST, Taper ML, Marshall TC (2007) Revising how the computer program CERVUS accommodates genotyping error increases success in paternity assignment. Mol Ecol 16:1099-1106

Katona S, Baxter B, Brazier O, Kraus S, Perkins J, Whitehead $\mathrm{H}$ (1979) Identification of humpback whales by fluke photographs. In: Winn HE, Olla BL (eds) Behavior of marine mammals, Vol 3: Cetaceans. Springer, Boston, MA

Kniest E, Burns D, Harrison P (2010) Fluke Matcher: a computer-aided matching system for humpback whale (Megaptera novaeangliae) flukes. Mar Mamm Sci 26:744-756

Krützen MC (2002) Molecular relatedness, paternity and male alliances in bottlenose dolphins (Tursiops sp.) in Shark Bay, Western Australia. PhD thesis, University of New South Wales, Sydney

Lambertsen RH, Baker CS, Weinrich M, Modi WS (1994) An improved whale biopsy system designed for multidisciplinary research. In: Fossi MC, Leonzio C (eds) Nondestructive biomarkers in vertebrates. CRC Press, Boca Raton, FL, p 219-244

Lento GM, Patenaude NJ, Baker CS (1997) Molecular genetic identification of whale and dolphin products for sale in Japan and Korea, 1995-97. Submission to the Scientific Committee of the International Whaling Commission, SC/49/O21
Lewis N, Day JC, Wilhelm A, Wagner D and others (2017) Large-scale marine protected areas: guidelines for design and management. IUCN, Gland

Lund JN, Josephson EA, Randall RR, Smith TD (2018) American offshore whaling voyages: a database. World Whaling History, National Maritime Digital Library. www. nmdl.org (accessed April 2018)

Miller C, Batibasiga A, Solomona P (2015) Very low numbers of endangered Oceania humpback whales seen in Fijian waters. South Pac J Nat Appl Sci 33:39-45

Minton G, Collins T, Findlay KP, Ersts PJ, Rosenbaum HC, Berggren P, Baldwin R (2011) Seasonal distribution, abundance, habitat use and population identity of humpback whales in Oman. J Cetacean Res Manag Spec Issue 3:185-198

* Morin PA, Martien KK, Archer FI, Cipriano F, Steel D, Jackson J, Taylor BL (2010) Applied conservation genetics and the need for quality control and reporting of genetic data used in fisheries and wildlife management. J Hered 101:1-10

*Munger LM, Lammers MO, Fisher-Pool P, Wong K (2012) Humpback whale (Megaptera novaeangliae) song occurrence at American Samoa in long-term passive acoustic recordings, 2008-2009. J Acoust Soc Am 132: 2265-2272

Noad M, Dunlop R, Paton D, Cato D (2011) Absolute and relative abundance estimates of Australian east coast humpback whales (Megaptera novaeangliae). J Cetacean Res Manag Spec Issue 3:243-252

Notarbartolo di Sciara G, Hoyt E, Reeves R, Ardron J, Marsh H, Vongraven D, Barr B (2016) Place-based approaches to marine mammal conservation. Aquat Conserv 26: $85-100$

* Olavarría C, Baker CS, Garrigue C, Poole M and others (2007) Population structure of humpback whales throughout the South Pacific and the origin of the eastern Polynesian breeding grounds. Mar Ecol Prog Ser 330: 257-268

* Oremus M, Garrigue C (2014) Humpback whale surveys in the Chesterfield Archipelago: a reflection using 19th century whaling records. Mar Mamm Sci 30:827-834

* Palsbøll PJ, Allen J, Berubé M, Clapham PJ and others (1997a) Genetic tagging of humpback whales. Nature 388:767-769

*Palsbøll PJ, Bérubé M, Larsen AH, Jorgensen H (1997b) Primers for the amplification of tri- and tetramer microsatellite loci in baleen whales. Mol Ecol 6:893-895

Peakall R, Smouse PE (2006) Genalex 6: genetic analysis in Excel. Population genetic software for teaching and research. Mol Ecol Notes 6:288-295

Pomilla C, Rosenbaum HC (2006) Estimates of relatedness in groups of humpback whales (Megaptera novaeangliae) on two wintering grounds of the Southern Hemisphere. Mol Ecol 15:2541-2555

Poole MM (2002) Occurrence of humpback whales (Megaptera novaeangliae) in French Polynesia 1988-2001. Report SC54/H14 to the Scientific Committee of the International Whaling Commission

Kead TC, FitzSimmons NN, Wantiez L, Jensen MP and others (2015) Mixed stock analysis of a resident green turtle, Chelonia mydas, population in New Caledonia links rookeries in the South Pacific. Wildl Res 42:488-499

Sambrook J, Fritsch EF, Maniatis T (1989) Molecular cloning: a laboratory manual. Cold Spring Harbor Laboratory Press, New York, NY 
Schlötterer C, Amos B, Tautz D (1991) Conservation of polymorphic simple sequence loci in cetacean species. Nature 354:63-65

Smith TD, Reeves RR, Josephson EA, Lund JN (2012) Spatial and seasonal distribution of American whaling and whales in the age of sail. PLOS ONE 7:e34905

Steel D, Anderson M, Garrigue C, Olavarría C and others (2018) Migratory interchange of humpback whales (Megaptera novaeangliae) among breeding grounds of Oceania and connections to Antarctic feeding areas based on genotype matching. Polar Biol 41:653-662

Townsend $\mathrm{CH}$ (1935) The distribution of certain whales as shown by logbook records of American whaleships. Zool Sci Contrib N Y Zool Soc 19:3-50

Valsecchi E, Amos W (1996) Microsatellite markers for the study of cetacean populations. Mol Ecol 5:151-156

V Valsecchi E, Corkeron PJ, Galli P, Sherwin W, Bertorelle G (2010) Genetic evidence for sex-specific migratory be-

Editorial responsibility: Mike Bruford,

Cardiff, UK haviour in western South Pacific humpback whales. Mar Ecol Prog Ser 398:275-286

* Waldick RC, Brown MW, White BN (1999) Characterization and isolation of microsatellite loci from the endangered North Atlantic right whale. Mol Ecol 8: 1763-1765

* White TD, Carlisle AB, Kroodsma DA, Block BA and others (2017) Assessing the effectiveness of a large marine protected area for reef shark conservation. Biol Conserv 207: 64-71

* Wilhelm TA, Sheppard CRC, Sheppard ALS, Gaymer CF, Parks J, Wagner D, Lewis N (2014) Large marine protected areas-advantages and challenges of going big. Aquat Conserv 24:24-30

Z Zerbini AN, Baumgartner MF, Kennedy AS, Rone BK, Wade PR, Clapham PJ (2015) Space use patterns of the endangered North Pacific right whale Eubalaena japonica in the Bering Sea. Mar Ecol Prog Ser 532:269-281

Submitted: October 2, 2019; Accepted: April 7, 2020

Proofs received from author(s): May 29, 2020 